\title{
Pedagogical mediations for non-formal nursing teaching during the COVID-19 pandemic
}

\author{
Mediações pedagógicas de ensino não formal da enfermagem durante a pandemia de COVID-19 \\ Mediaciones pedagógicas de la educación no formal en enfermería durante la pandemia del COVID-19
}

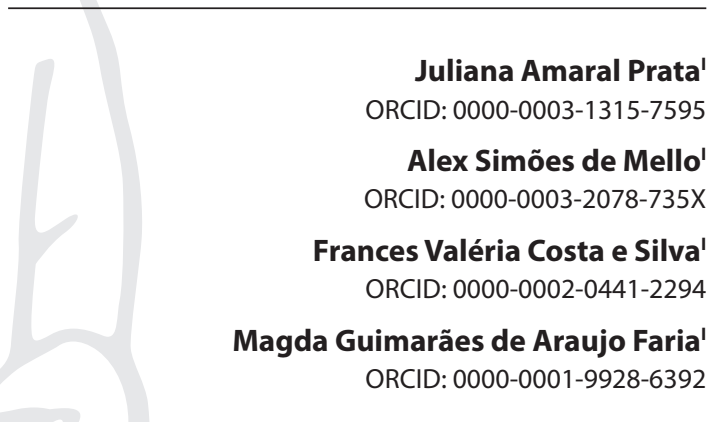

'Universidade do Estado do Rio de Janeiro. Rio de Janeiro, Rio de Janeiro, Brazil

How to cite this article: Prata JA, Mello AS, Costa e Silva FV, Faria MGA. Pedagogical mediations for non-formal nursing teaching during the COVID-19 pandemic. Rev Bras Enferm. 2020;73(Suppl 2):e20200499. doi: http://dx.doi.org/10.1590/0034-7167-2020-0499

\section{Corresponding author:} Juliana Amaral Prata E-mail: juaprata@gmail.com

EDITOR IN CHIEF: Dulce Barbosa ASSOCIATE EDITOR: Ana Fátima Fernandes

Submission: 05-08-2020

Approval: 09-07-2020

\begin{abstract}
Objective: to report the experience of developing pedagogical mediations in a Virtual Learning Environment implemented in a nursing faculty during the COVID-19 pandemic. Methods: an experience report on the construction of a distance course aimed at graduates and residents of a nursing faculty at a public university located in the city of Rio de Janeiro. Results: the course's conception, operationalization and implementation were the result of a collective work that culminated in a non-formal, virtual and problematic teaching process, which reached a participation rate of $82 \%$ of enrolled students. Final considerations: even in times of social isolation, the course promoted collaborative learning of knowledge about COVID-19 and strengthened the relationship between professors and students. The possibility of carrying out distance activities based on solid methodological proposals that contradict the content logic often observed in distance learning is emphasized.
\end{abstract}

Descriptors: Nursing; Learning; Pandemics; Coronavirus Infections; Education, Distance.

\section{RESUMO}

Objetivo: relatar a experiência do desenvolvimento de mediações pedagógicas em Ambiente Virtual de Aprendizagem implementadas em uma faculdade de enfermagem durante a pandemia de COVID-19. Métodos: relato de experiência da construção de um curso a distância voltado para graduandos e residentes de uma faculdade de enfermagem de uma universidade pública situada no município do Rio de Janeiro. Resultados: a concepção, operacionalização e implementação do curso foi fruto de um trabalho coletivo que culminou em um processo de ensino não formal, virtual e problematizador, o qual alcançou taxa de participação de $82 \%$ dos educandos inscritos. Considerações finais: mesmo em tempos de isolamento social, o curso promoveu a aprendizagem colaborativa de conhecimentos acerca da COVID-19, estreitando as relações entre docentes e educandos. Ressalta-se a possibilidade de realizar atividades a distância baseadas em propostas metodológicas sólidas que contrariam a lógica conteudista frequentemente observada na Educação a Distância.

Descritores: Enfermagem; Aprendizagem; Pandemias; Infecção por Coronavírus; Educação a Distância.

\section{RESUMEN}

Objetivo: reportar la experiencia de desarrollo de mediaciones pedagógicas en un Ambiente Virtual de Aprendizaje implementado en una facultad de enfermería durante la pandemia de COVID-19. Métodos: relato de experiencia en la construcción de un curso a distancia dirigido a estudiantes y residentes de una facultad de enfermería de una universidad pública ubicada en la ciudad de Río de Janeiro. Resultados: la concepción, operacionalización e implementación del curso fue el resultado de un trabajo colectivo que culminó en un proceso docente no formal, virtual y problemático, que alcanzó una tasa de participación del $82 \%$ de los estudiantes matriculados. Consideraciones finales: incluso en tiempos de aislamiento social, el curso promovió el aprendizaje colaborativo de conocimientos sobre COVID-19, fortaleciendo las relaciones entre profesores y alumnos. Se enfatiza la posibilidad de realizar actividades a distancia basadas en propuestas metodológicas sólidas que contradicen la lógica de contenido frecuentemente observada en Educación a Distancia.

Descriptores: Enfermería; Aprendizaje; Pandemias; Infecciones por Coronavirus; Educación a Distancia. 


\section{INTRODUCTION}

The pandemic caused by the uncontrolled advance of coronavirus disease 2019 (COVID-19) reached Brazil in March 2020(1), demanding quick responses from autochthonous transmission identification. This scenario highlighted the need to offer subsidies to students in the health field, especially those in advanced training stages, for safe assistance, without losing sight of the quality of teaching.

In this context, there are graduate students in supervised curricular internship and nursing residents in different professional training programs anchored in in-service teaching, for which the adoption of social isolation measures ${ }^{(2)}$ coincided with the beginning of activities in the first academic semester, mainly in the state of Rio de Janeiro.

Considering the impossibility of maintaining academic activities, it became imperative to critically reflect on the practical training of undergraduate students and residents of health institutions. It is understood that the aggregation of theoretical and practical knowledge is essential for developing attitudes, skills and competences necessary for safe care for students and users.

In this regard, it is understood that the current epidemiological overview constitutes a limitation for formal classroom teaching. However, distance learning (DL) appears as a viable strategy, as it is a modality of teaching and learning in which educator and student do not share the same physical space or chronological moment, in all or part of the learning path, having its heart in interactive relationships through a telecommunication process ${ }^{(3)}$.

Developing a DL course on coping with COVID-19 was envisaged in order to enhance the sharing of experiences among peers, combat fake news, develop citizen awareness and build non-formal education actions within possibilities of the current context. Thus, the management of training is registered in a nursing faculty of a public university, located in the city of Rio de Janeiro.

The course design followed the theoretical concept of teaching virtualization, which considers the virtual environment as a fertile space for generating and updating knowledge, combining the creative potential of participants with the nomadic aspect of temporal and geographical abstention to materialize the educational process, making it real, despite not being in site ${ }^{(4)}$. Under this perspective, the course organization was based on problematization as a central axis to build knowledge through pedagogical mediations in a Virtual Learning Environment (VLE).

Experiences about using technological resources to implement DL activities, especially for non-curricular purposes, such as those aimed at professional qualification, are encouraged by the Federal Nursing Council (Conselho Federal de Enfermagem) (5). Moreover, a database survey conducted in April 2020 using the Boolean phrase "distance learning" and "nursing students" and "training" found 114 results, of which only three publications were from national experiences.

Considering the gap existing in the construction and socialization of Brazilian initiatives on VLE use in nursing, sharing successful experiences is necessary, especially in atypical scenarios, such as the current pandemic, which require rapid training of nursing professionals, imposing limitations for develop classroom teaching practices.

\section{OBJECTIVE}

To report the experience of developing pedagogical mediations in a VLE implemented in a nursing faculty during the COVID-19 pandemic.

\section{METHODS}

This is an experience report with a descriptive approach on the development of emergency non-formal education actions for graduates and residents of a nursing faculty at a public university located in the city of Rio de Janeiro. The experience took place between March and April 2020 with organizational activities carried out entirely through digital technologies.

Aiming at bringing students and professors closer to the emerging theme in public health, Undergraduate Teaching Coordination (UTG) created the Coping with COVID-19 Course in the form of an introductory non-formal education project in VLE. The course was conceived, operated and offered as free and autonomous participation, without obligation or attribution to any administrative work or formal teaching process.

Using VLE's Modular Object-Oriented Dynamic Learning Environment (Moodle) software linked to the University's Undergraduate Dean's Office, the course was structured in three thematic blocks. These blocks contained didactic materials and activities oriented by problematization(6), associating diverse forms of content presentation with pedagogical mediations, totaling a workload of 30 hours.

From conception to implementation of the course, it was an intense journey that encompassed many comings and goings. It was up to UTG to mobilize a group of 44 professors who were willing to collaborate in the operationalization, organizing it in three teams: Central Working Group, composed of 15 professors and two nurses linked to the university's assistance units, responsible for the construction of teaching materials; Mentoring Group, with 27 professors, involved in the mediation process in VLE; Technical and Pedagogical Support Group, with four professors who wove the project's structure and monitored its development.

Implemented on 03/27/2020, the course's initial offer had a target audience of 279 students, of which 229 had records of access and participation in VLE, with 54 interns from the last year of nursing undergraduate and 176 resident nurses from the first and second year of the institution's Nursing Residency Programs. Moreover, 17 professors expressed interest in participating as listeners, and were brought together in a single group without tutoring pedagogical mediation.

This article did not require evaluation by a Research Ethics Committee, as it did not involve participants in an investigation or intervention.

\section{RESULTS}

The experience followed the path proposed by the instructional design in online education ${ }^{(7)}$ and its report was divided into three moments: The conception of the Coping with COVID-19 Course; From operationalization to implementation of the course: the sum of efforts; The technical and pedagogical support group's view on the educational proposal. 


\section{Conception of the Coping with COVID-19 course}

The first moment of this experience consisted of planning the course, which began by identifying the emergency demands for specific learning about the pandemic, the target audience, and the objectives to be achieved. It culminated in the understanding that the course would be a non-formal teaching activity. This modality involves sharing experiences and collective discussion in everyday spaces, not necessarily institutional, as educational processes that articulate values, cultures and subjectivities to awaken a critical eye on a context in which educational action is circumscribed, with a view to promoting citizenship of agents involved and transforming the reality in which they are inserted ${ }^{(6)}$.

Although there was a need for virtualization of the course due to social isolation, the next step was to elaborate a pedagogical architecture to materialize it as a problematic, open, spontaneous teaching and learning process, with free and continuous access to information, built from virtual interactions and collective reflections on facts, objects and people in the context of COVID-19 (Figure 1).

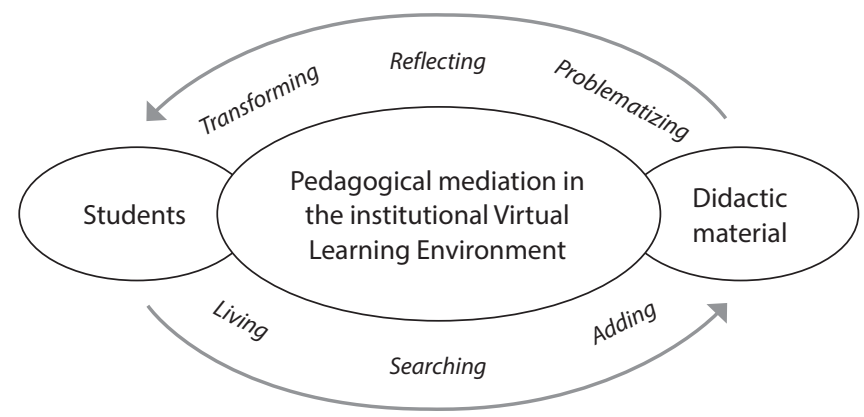

Note: COVID-19- coronavirus disease 2019.

Figure 1 - Pedagogical architecture of the Coping with COVID-19 course

Based on interactive relationships that use telecommunication ${ }^{(8)}$ and problematization ${ }^{(6)}$, the course pedagogical architecture was designed with the purpose of constituting dialogic spaces conducive to sharing knowledge and experiences in a horizon of qualification of care practices of those who are in the services. It also aimed at offering educational and sensitive care amidst the pandemic, aimed at the dissemination of appropriate community guidelines and the promotion of mental health in the context of social isolation.

Subsequently, it was decided that the course would be organized in three thematic blocks, dealing with relevant contents of the pandemic context combined with the scope of nursing practices ${ }^{(9)}$, epidemiological overview, clinical and care management, complications and specificities. To guide the construction of teaching materials, a lesson plan model ${ }^{(7,10)}$ was created containing the following information: thematic block, title of the activity, theme addressed, objective to be achieved, activity length for students and tutors, pedagogical strategy, what is expected from students and tutors, related materials, and complementary bibliographies.

It is noteworthy that this strategy also aimed to ensure a certain uniformity and fluidity between the different activities of the thematic blocks of the course and to watch over the pedagogical process based on problematization ${ }^{(6)}$ that guides the institution's curriculum, even when teaching practices develop virtually.
Therefore, in opposition to the content logic commonly adopted by most educational resources available in the virtual environment ${ }^{(8)}$, the course proposed to use didactic materials, and was based on pedagogical mediations between tutors and students to encourage specific knowledge exploration about COVID-19 and provide an exchange of experiences. Thus, it was possible to collaboratively build knowledge and solidarity from a dialogical and problematizing perspective, which would pave the way for critical and reflective action of health action ${ }^{(6,8,10)}$.

\section{From operationalization to implementation of the course: the sum of efforts}

The second part of this experience was dedicated to fundraising, preparation of teaching materials, definition of forms of interaction, appropriation of technological means and specific technical processes related to the course preparation and organization in VLE, a phase that included registration, training and setting of professors and students.

This process took place over a period of 10 days $(03 / 16 / 2020$ to $03 / 26 / 2020$ ), which required a collective work on multiple fronts conducted by the Technical and Pedagogical Support Group, which sought potential collaborators who had an approximation with the contents listed for the thematic blocks and previous experience in VLE use, reaching 44 teaching partnerships.

Under the coordination of two professors, the teaching materials for each block were produced by the Central Working Group, which streamlined the search and construction of activities for an introductory theme exploration with support of tutors. In this regard, the group developed didactic strategies widely used in virtual environments, such as video classes, educational and artistic videos, images, poems, texts with verbal and non-verbal language, reports, articles and technical-scientific documents; they were made available in association with different activities that trigger discussions and reflections in forums and chats ${ }^{(7-8,10)}$.

As a result of the work of this group, the thematic blocks had a new configuration, the first and second being divided into three parts, and the third, distributed in five, as shown in Chart 1.

As part of the course operationalization, the Technical and Pedagogical Support Group was dedicated to organizing the set of teaching materials in VLE. This activity lasted for about three days and was carried out entirely by nursing professors, which demonstrates the feasibility of courses of this nature being built by nursing, even in the absence of specific training for this purpose.

Subsequently, the Mentoring Group, responsible for pedagogical mediation between students and materials in VLE, was invited for a brief training and setting of tutors ${ }^{(7)}$, in which they became familiar with the lesson plans of each thematic block in VLE for two days. This initiative was essential, considering that many tutors were insecure with little appropriation of the emerging theme and, in many cases, because it represents a first approach to non-formal teaching and the use of digital resources for pedagogical purposes.

In addition to these training dynamics, we opted for organizing tutoring in pairs of professors with different nursing specialties, one with expertise in primary care and the other in hospital care, with the aim of qualifying the mediation process. Another resource employed was the creation of a direct communication channel between the Mentoring Group members through a messaging application. 
Chart 1 - Organization of thematic blocks of the course

\begin{tabular}{|c|c|c|}
\hline Block & Length & Objetivos pedagógicos \\
\hline $\begin{array}{c}\text { Epidemiological } \\
\text { overview }\end{array}$ & 3 days & $\begin{array}{l}\text { - Encourage reflective dialogue on the } \\
\text { context of the pandemic caused by } \\
\text { COVID-19; } \\
\text { - Highlight epidemiological aspects, } \\
\text { conceptual approaches and ethical issues } \\
\text { that involve the nature of a pandemic event. }\end{array}$ \\
\hline $\begin{array}{c}\text { Clinical } \\
\text { and care } \\
\text { management }\end{array}$ & 3 days & $\begin{array}{l}\text { - Present a set of techniques and } \\
\text { procedures of nursing practice in direct } \\
\text { care for symptomatic or confirmed } \\
\text { patients, discuss infection control } \\
\text { measures and the health of health } \\
\text { workers in the context of COVID-19; } \\
\text { - Know the clinical management of } \\
\text { respiratory syndromes. }\end{array}$ \\
\hline $\begin{array}{l}\text { Complications } \\
\text { and specificities }\end{array}$ & 4 days & $\begin{array}{l}\text { - Identify situations of worsening of the } \\
\text { disease, know care protocols in Intensive } \\
\text { Care Units; } \\
\text { - Discuss care for special groups affected } \\
\text { by COVID-19 (children, elderly people, } \\
\text { pregnant women, women in labor and } \\
\text { mothers); } \\
\text { - Reflect on the ethical and bioethical aspects } \\
\text { of health care in the pandemic scenario. }\end{array}$ \\
\hline
\end{tabular}

These strategies brought professors closer together and formed spaces for permanent education for tutors, which made it possible to share specific knowledge from COVID-19 and experiences on the interaction with students and the use of digital tools throughout the course. Furthermore, it provided a space of care through sensitive listening and welcoming the experiences of suffering in the context of the pandemic ${ }^{(9)}$.

At the same time, UTG collected data on nursing interns and residents, in order to streamline the process of enrolling and distributing students in a VLE. Students were divided into 11 virtual classes, respecting the ratio of a maximum of 25 students for each 2 tutors; this allowed establishing welcoming and empathic relationships, as well as favoring the organic construction of knowledge ${ }^{(8,10)}$ about the emerging theme of COVID-19.

In dialogue with the empathy essential to the context lived, from which sufferings, concerns, anxieties, losses and singular ways of coping with social distancing emerge, especially from university life ${ }^{(9)}$, we resort to lovingly teaching pedagogical action in welcoming students ${ }^{(6)}$ in a VLE. In this sense, a video was built, accompanied by a welcome message, in order to soften the technical nature of the theme and the apparently harsh perspective of digital information and communication technologies ${ }^{(7)}$.

\section{The technical and pedagogical support group's view on the educational proposal}

As an essential part of the entire teaching and learning process, the Technical and Pedagogical Support Group was in charge of monitoring and assessing the course from its implementation, on March 27, until its completion, on April 10, 2020.

During the educational proposal, it was identified the need to extend the course length for another four days, since 176 students
(78\%) were nursing residents who worked on the front line of coping with COVID-19. They found limitations to participate in the proposed daily activities due to the workday, as well as physical and psychological exhaustion due to assistance in the current scenario of the Unified Health System (SUS - Sistema Único de Saúde), in conditions that are often strenuous and precarious in terms of material and human resources.

Despite not being mandatory, it is understood that the course had a good adhesion, even though experiences of suffering and difficulties in accessing the internet may have been configured as limiting factors for the participation of a small group of students. This perception is based on significant material exploitation made available and interaction with tutors by 229 students (82\%) of a total of 279 enrolled.

In spite of these notes, it was possible to notice that the sharing of experiences between students, residents and tutors offered the dialogical basis and the kindness necessary for sensitive reception and the development of citizen awareness. Likewise, the exchange of information has brought support to a discursive practice capable of deflating, with consistent arguments, the flood of fake news that has flooded social networks ${ }^{(9)}$.

\section{Study limitations}

Considering that this educational experience is related to an emergency and atypical context of Brazilian public health, its development faced time as a limiting factor of the potential that the course offered. Thus, it had repercussions in absence of prior consultation with students on internet access; difficulties in accessing the course with smartphones; insufficient disclosure; damage to better use by students. Another limiting factor was lack of proximity to the functionalities of VLE, which led to underutilization of its resources by all involved.

\section{Contributions to nursing, health, and public policies}

The present experience subsidized reflections about VLE activities as a complementary resource to teaching in nursing, when developed from a problematic perspective and through intentional pedagogical mediations.

In this perspective, the potential of teaching virtualization pointed out in this experience brings contributions to public policies. They establish a new perspective on $\mathrm{DL}$ for the training of human resources in health, particularly in non-formal and continuing education activities, demystifying the common sense about this modality and the lack of technical knowledge as a limiting factor for its implementation.

\section{FINAL CONSIDERATIONS}

As academic activities were suspended due to the pandemic, the present report experience was considered an efficient organic strategy that promoted collaborative learning of knowledge about COVID-19 and strengthened the relations between professors and students, even in times of social isolation.

Furthermore, from the perspective of pedagogical practices, the professors saw the potential of using VLE through 
technological mediations based on problematization, contrary to the content logic often observed in DL. Therefore, it is believed that this experience of non-formal education functioned as an experimentation that provided the acquisition of essential knowledge to plan formal education in a future return to university life, which will face challenges in person, considering COVID-19's epidemiological characteristics and the structural weaknesses of universities in Brazil.
On the other hand, even though digital accessibility may have represented a limitation for some students, the high percentage of access to the course reveals the possibility of implementing distance activities for theoretical and theoretical-practical teaching in nursing. This occurs considering the probable health need for adopting a hybrid teaching and learning process through inclusive actions that favor participation of all and safeguarding the essentiality of classroom teaching for nurses' practical training.

\section{REFERENCES}

1. Rafael RMR, Mercedes Neto M, Carvalho MB, Acioli S, David MSL, Faria MGA. Epidemiology, public policies and Covid-19 pandemics in Brazil: what can we expect? Rev Enferm UERJ. 2020;28:e49570. doi: 10.12957/reuerj.2020.49570

2. Governo do Estado do Rio de Janeiro. Decreto no 46.973, de 16 de março de 2020. Reconhece a situação de emergência na saúde pública do Estado do Rio de Janeiro em razão do contágio e adota medidas enfrentamento da propagação decorrente do novo coronavírus (covid-19); e dá outras providências. Diário Oficial do Estado do Rio de Janeiro. 18 março 2020.

3. Logan JW, Lundberg OH, Roth L, Walsh KR. The effect of individual motivation and cognitive ability on student performance outcomes in a distance education environment. J Learn Higher Educ [Internet]. 2017 [cited 2020 May 5];13(1):83-91. Available from: https://files.eric. ed.gov/fulltext/EJ1139727.pdf

4. Lévy P. O Que é virtual? São Paulo: Editora 34; 2011. 157p.

5. Conselho Federal de Enfermagem. Quatro perguntas sobre o COFEN e a EAD na enfermagem [Internet]. Brasília: 27 jan 2017 [cited 2020 May 5]. Available from: http://www.cofen.gov.br/4-perguntas-sobre-o-cofen-e-o-ead-na-enfermagem_48429.html

6. Freire P. Pedagogia do Oprimido. Rio de Janeiro: Paz \& Terra; 2019. 256p.

7. Matsubara MGS, Domenico EBLD. Building a virtual learning environment for distance education in nursing oncology. Int Arch Nurs Health Care. 2016;2(3):049. doi: 10.23937/2469-5823/1510049

8. Fofonca E, Schoninger RRZV, Costa CS. A mediação tecnológica e pedagógica em ambientes virtuais de aprendizagem: contribuições da educomunicação. Rev Tempos Espaços Educ. 2018;11(24):267-78. doi: 10.20952/revtee.v11i24.6031

9. Cavalcante ASP, Machado LDS, Farias QLT, Pereira WMG, Silva MRF. Higher education in health care studies: distance education in Brazil amid the crisis of the new coronavirus. Av Enferm. 2020;38(1 supl):113-21. doi: 10.15446/av.enferm.v38n1supl.86229.

10. Avelino CCV, Costa LCS, Buchhorn SMM, Nogueira DA, Goyatá SLT. Teaching-learning evaluation on the ICNP ${ }^{\otimes}$ using virtual learning environment. Rev Bras Enferm. 2017;70(3):602-9. doi: 10.1590/0034-7167-2016-0545 